\title{
Kedudukan PT. Angkasa Pura I Dalam Pembayaran Bea Perolehan Hak Atas Tanah Dan Bangunan
}

\author{
Ridwan, Nurmalita Ayuningtyas Harahap, dan Siti Ruhama Mardhatillah \\ Fakultas Hukum Universitas Islam Indonesia \\ Jln. Tamansiswa No. 158 Yogyakarta \\ ridwanhr67@gmail.com; 154101306@uii.ac.id, dan titilaw10@gmail.com
}

Received: 31 Mei 2018; Accepted: 4 Februari 2019; Published: 24 April 2019

DOI: 10.20885/iustum.vol26.iss1.art8

\begin{abstract}
This paper examines the issues of, first, the special assignment of the Minister of BUMN (State Owned Enterprise) and the Minister of Transportation to PT. Angkasa Pura I (Persero) in land procurement for the construction of the New Yogyakarta International Airport (NYIA) airport in Kulon Progo Regency, DIY Province whether it can invalidate the obligations of PT. Angkasa Pura I (Persero) to pay BPHTB. Second, it is regarding the land procurement for the construction of the New Yogyakarta International Airport (NYIA) airport in Kulon Progo Regency, Special District of Yogyakarta whether it can be qualified as "land acquisition for the development of public interest" which is freed from the obligation to pay BPHTB. This is a normative legal research using primary and secondary legal materials obtained through literature studies and is analyzed juridical. From the research results, it can be concluded that, first, special assignments could not invalidate the obligations of PT. Angkasa Pura I (Persero) to pay BPHTB. Secondly, PT. Angkasa Pura I (Persero) in Kulon Progo Regency of Special District of Yogyakarta Province cannot be qualified as "land acquisition for development for public interest" freed from the obligation to pay BPHTB.
\end{abstract}

Keywords: Customs and Land Rights Acquisition Fees (BHTB); PT. Angkasa Pura I (Persero); Kulon Progo

\begin{abstract}
Abstrak
Permasalahan yang diteliti dalam naskah ini, yaitu pertama, mengenai penugasan khusus Menteri BUMN dan Menteri Perhubungan kepada PT. Angkasa Pura I (Persero) dalam pengadaan tanah untuk pembangunan bandara New Yogyakarta International Airport (NYIA) di Kabupaten Kulon Progo Provinsi DIY apakah menggugurkan kewajiban PT. Angkasa Pura I (Persero) untuk membayar BPHTB. Kedua, mengenai pengadaan tanah untuk pembangunan bandara New Yogyakarta International Airport (NYIA) di Kabupaten Kulon Progo Provinsi DIY apakah dapat dikualifikasi sebagai "pengadaan tanah untuk pembangunan guna kepentingan umum" yang dibebaskan dari kewajiban membayar BPHTB. Penelitian ini merupakan penelitian hukum normatif dengan menggunakan bahan hukum primer dan sekunder yang diperoleh melalui studi kepustakaan serta dianalisis secara yuridis. Hasil penelitian menyimpulkan bahwa, pertama penugasan khusus tidak dapat menggugurkan kewajiban PT. Angkasa Pura I (Persero) untuk membayar BPHTB. Kedua, PT. Angkasa Pura I (Persero) di Kabupaten Kulon Progo Provinsi DIY tidak dapat dikualifikasi sebagai "pengadaan tanah untuk pembangunan guna kepentingan umum" yang dibebaskan dari kewajiban membayar BPHTB.
\end{abstract}

Kata-kata Kunci: Bea Perolehan Hak atas Tanah dan Bangunan (BHTB); PT. Angkasa Pura I (Persero); Kulon Progo 


\section{Pendahuluan}

Kegiatan pembangunan dapat dilakukan oleh lembaga negara, Kementerian, Lembaga Pemerintah Non Kementerian, Badan Usaha Milik Negara, Badan Usaha Milik Daerah. Untuk melaksanakan kegiatan pembangunan tersebut dibutuhkan tanah sebagai wadah kegiatannya. ${ }^{1}$ Berdasarkan Pasal 4 ayat (1) dan 10 huruf d Undang-Undang Nomor 2 Tahun 2012 tentang Pengadaan Tanah bagi Pembangunan untuk Kepentingan Umum, Pemerintah dan/atau Pemerintah Daerah menjamin tersedianya tanah untuk kepentingan umum, diantaranya untuk pembangunan bandar udara. Dalam hal instansi yang memerlukan tanah itu BUMN, pengadaannya dilakukan melalui penugasan khusus, dengan pendanaan yang bersumber dari internal perusahaan, dan tanahnya kemudian menjadi milik BUMN.

PT. Angkasa Pura I (Persero) mendapatkan penugasan khusus dari Menteri BUMN No. S-729/MBU/2013 tanggal 9 Desember 2013, dan dari Menteri Perhubungan No. AP.I.6493/HK.02/2014/PD-B tanggal 19 Desember 2014, serta Surat Keputusan Menteri Perhubungan No. KP. 280 Tahun 2015 tentang Penugasan Khusus kepada PT. Angkasa Pura I (Persero) dalam rangka percepatan proses pengadaan tanah bagi pembangunan bandara untuk kepentingan umum di Kabupaten Kulon Progo Provinsi DIY.

Penyelenggaraan pengadaan tanah itu sendiri akan membawa konsekuensi hukum (rechtsgevolg) yang berupa peralihan hak atas tanah dari pemilik tanah kepada pihak yang memerlukan tanah. Pada peralihan hak atas tanah itu, kepada pemilik dibebani kewajiban membayar pajak penghasilan (PPh) atas penghasilan yang diperoleh dari peralihan hak atas tanah dan bagi pihak yang memerlukan tanah (memperoleh hak atas tanah) dibebani kewajiban membayar Bea Perolehan Hak atas Tanah dan Bangunan (BPHTB).

Berdasarkan Pasal 1 angka 41 dan 42 Undang-Undang Nomor 28 Tahun 2009 tentang Pajak Daerah dan Retribusi Daerah disebutkan; “Bea Perolehan Hak atas Tanah dan Bangunan (BPHTB) adalah pajak atas perolehan hak atas tanah dan/atau bangunan", dan "Perolehan hak atas tanah dan/atau bangunan adalah perbuatan atau

${ }^{1}$ Urip Santoso, "Perolehan Hak Atas Tanah yang Berasal dari Reklamasi Pantai," Mimbar Hukum, Universitas Gadjah Mada, Volume 27, Nomor 2, Juni 2015, Yogyakarta, hlm. 215. 
peristiwa hukum yang mengakibatkan diperolehnya hak atas tanah dan/atau bangunan oleh orang pribadi atau badan", dan selanjutnya dalam Pasal 86 disebutkan bahwa subjek dan wajib BPHTB adalah orang pribadi dan badan, yaitu

"Sekumpulan orang dan/atau modal yang merupakan kesatuan, baik yang melakukan usaha maupun yang tidak melakukan usaha yang meliputi perseroan terbatas, perseroan komanditer, perseroan lainnya, badan usaha milik negara (BUMN), atau badan usaha milik daerah (BUMD) dengan nama dan dalam bentuk apa pun, firma, kongsi, koperasi, dana pensiun, persekutuan, perkumpulan, yayasan, organisasi massa, organisasi sosial politik, atau organisasi lainnya, lembaga dan bentuk badan lainnya termasuk kontrak investasi kolektif dan bentuk usaha tetap,"

Sebagaimana ditentukan dalam Pasal 1 angka 11 Undang-Undang Nomor 28 Tahun 2009 tentang Pajak Daerah dan Retribusi Daerah. Konsideran UndangUndang Nomor 28 Tahun 2009 secara implisit menyatakan bahwa tujuan dikeluarkannya undang-undang tersebut adalah dalam rangka memberi dukungan kepada keuangan daerah dengan cara peningkatan perluasan objek pajak daerah dan retribusi daerahdan pemberian diskresi dalam penetapan tarif. ${ }^{2}$

Undang-Undang Pajak Daerah dan Retribusi Daerah dan Peraturan Daerah Kabupaten Kulon Progo Nomor 9 Tahun 2010 tentang Bea Perolehan Hak atas Tanah dan Bangunan, pemungutan BPHTB meliputi berbagai perolehan hak atas tanah dan bangunan seperti jual beli, tukar menukar, hibah, waris, dan sebagainya, namun berdasarkan Pasal 85 ayat (4) Undang-Undang Nomor 28 Tahun 2009 dan Pasal 4 Peraturan Daerah Kabupaten Kulon Progo Nomor 9 Tahun 2010, pemungutan BPHTB ini dikecualikan terhadap hal-hal berikut ini:

a. Perwakilan diplomatik dan konsulat berdasarkan asas perlakuan timbal balik;

b. Negara untuk penyelenggaraan pemerintahan dan/atau untuk pelaksanaan pembangunan guna kepentingan umum;

c. Badan atau perwakilan lembaga internasional yang ditetapkan dengan Peraturan Menteri Keuangan dengan syarat tidak menjalankan usaha atau melakukan kegiatan lain di luar fungsi dan tugas badan atau perwakilan organisasi tersebut;

d. Orang pribadi atau Badan karena konversi hak atau karena perbuatan hukum lain dengan tidak adanya perubahan nama;

e. Orang pribadi atau Badan karena wakaf; dan

f. Orang pribadi atau badan yang digunakan untuk kepentingan ibadah.

\footnotetext{
${ }^{2}$ Nabitatus Sa’adah, "Kelemahan Penerapan Closed List System Serta Implikasinya dalam Pemungutan Bea Perolehan Hak Atas Tanah dan Bangunan”, Masalab-Masalah Hukum Universitas Diponegoro Semarang, Jilid 43, No.1, Januari 2014, Semarang, hlm.135-136.
} 
Pemungutan BPHTB ini berlaku bagi setiap orang pribadi atau badan, yang memperoleh hak atas tanah dan/atau bangunan, dengan perkecualian sebagaimana ditentukan secara definitif dalam Pasal 85 ayat (4) Undang-Undang Nomor 28 Tahun 2009 dan Pasal 4 Peraturan Daerah Kabupaten Kulon Progo Nomor 9 Tahun 2010 tersebut.

Permasalahan ini muncul ketika PT. Angkasa Pura I (persero) menolak membayar BPHTB atas perolehan hak atas tanah dalam pembangunan bandar udara NYIA atas dasar bahwa pengadaan tanah tersebut tergolong pengadaan tanah untuk pembangunan guna kepentingan umum dengan dasar penugasan langsung yang diberikan oleh Menteri BUMN dan Menteri Perhubungan. Namun demikian, hal ini menjadi problematik jika dikaitkan dengan kedudukan PT. Angkasa Pura I (persero) sebagai Badan Usaha Milik Negara (BUMN) yang merupakan badan hukum privat dan tergolong badan yang dikenakan BPHTB menurut Undang-Undang Nomor 28 Tahun 2009 dan Pasal 4 Peraturan Daerah Kabupaten Kulon Progo Nomor 9 Tahun 2010.

Keadaan ini semakin menjadi persoalan yang tidak kunjung usai disebabkan terjadi ketidaksatuan kebijakan antar dirjen di Kementerian Keuangan. Direktorat Jenderal Perimbangan Keuangan melalui surat jawaban yang ditujukan kepada Bupati Kulon Progo Nomor S-393/PK/2017 menegaskan bahwa pengadaan tanah untuk pembangunan Bandara Baru Yogyakarta di Kulon Progo oleh PT. Angkasa Pura I termasuk dalam ruang lingkup kepentingan umum sehingga tidak dikenakan BPHTB sebagaimana dimaksud dalam Undang-Undang Nomor 28 Tahun 2009. Namun demikian, Direktorat Jenderal Pajak melalui surat jawaban Nomor S-1016/PJ.03/2015 yang ditujukan kepada Presiden Direktur PT. Angkasa Pura I menegaskan yang pada intinya bahwa pengadaan tanah untuk pembangunan bandar udara baru di Yogyakarta tidak termasuk dalam pengalihan hak atas tanah dan/atau bangunan kepada pemerintah guna pelaksanaan pembangunan untuk kepentingan umum. Selain itu, menurut Dirjen Pajak Kementerian keuangan dalam suratnya menegaskan bahwa PT. Angkasa Pura I bukanlah pemerintah, melainkan sebuah badan usaha yang dikenakan BPHTB atas peralihan hak atas tanah tersebut. 


\section{Rumusan Masalah}

Berdasarkan uraian latar belakang masalah diatas dapat ditarik 2 rumusan masalah sebagai berikut: Pertama, apakah penugasan khusus Menteri BUMN dan Menteri Perhubungan kepada PT. Angkasa Pura I (Persero) dalam pengadaan tanah untuk pembangunan bandara di Kabupaten Kulon Progo Provinsi DIY mengubah kedudukan PT. Angkasa Pura I (Persero) sehingga menggugurkan kewajibannya untuk membayar BPHTB? Kedua, apakah pengadaan tanah untuk pembangunan bandara di Kabupaten Kulon Progo Provinsi DIY dapat dikualifikasi sebagai "pengadaan tanah untuk pembangunan guna kepentingan umum" yang dibebaskan dari kewajiban membayar BPHTB?

\section{Tujuan Penelitian}

Tujuan dari penelitian ini adalah untuk mengkaji dan menemukan landasan ilmiah mengenai: Pertama, untuk mengetahui dan menganalisis apakah penugasan khusus Menteri BUMN dan Menteri Perhubungan kepada PT. Angkasa Pura I (Persero) dalam pengadaan tanah untuk pembangunan bandara di Kabupaten Kulon Progo Provinsi DIY mengubah kedudukan PT. Angkasa Pura I (Persero) sehingga menggugurkan kewajibannya untuk membayar ВРНTB. Kedua, untuk mengetahui dan menganalisis apakah pengadaan tanah untuk pembangunan bandara di Kabupaten Kulon Progo Provinsi DIY dapat dikualifikasi sebagai "pengadaan tanah untuk pembangunan guna kepentingan umum" yang dibebaskan dari kewajiban membayar BPHTB.

\section{Metode Penelitian}

Penelitian ini merupakan penelitian hukum normatif, yakni penelitian yang obyek kajiannya berupa norma-norma hukum, khususnya norma hukum yang berkaitan dengan Kedudukan dan Kewenangan PT. Angkasa Pura I (Persero) dalam Pembayaran Bea Perolehan Hak Atas Tanah berkenaan dengan Pengadaan Tanah untuk Pembangunan Bandara di Kulon Progo DIY.

Obyek penelitian berupa pembayaran Bea Perolehan Hak Atas Tanah oleh PT. Angkasa Pura I (Persero) pembangunan bandara di Kabupaten Kulon Progo DIY. 
Pendekatan yang digunakan dalam penelitian ini yaitu pendekatan peraturan perundang-undangan dan pendekatan konseptual.

Sumber data yang digunakan terdiri atas bahan hukum primer dan bahan hukum sekunder. Bahan-bahan hukum primer terdiri atas Undang-Undang Nomor 19 Tahun 2003 tentang Badan Usaha Milik Negara, Undang-Undang Nomor 2 Tahun 2012 tentang Pengadaan Tanah bagi Pembangunan untuk Kepentingan Umum, Undang-Undang Nomor 28 Tahun 2009 tentang Pajak Daerah dan Retribusi Daerah, Peraturan Daerah Kabupaten Kulon Progo Nomor 9 Tahun 2010 tentang Bea Perolehan Hak Atas Tanah dan Bangunan serta berbagai peraturan perundang-undangan lainnya yang terkait dengan obyek penelitian. Bahan hukum sekunder yang digunakan dalam penelitian ini terdiri atas bukubuku teks tentang hukum, terutama Hukum Administrasi, hasil-hasil penelitian di bidang hukum, jurnal-jurnal ilmiah bidang hukum, dan kamus-kamus hukum.

Data yang dikumpulkan kemudian dianalisis menggunakan teori-teori dan konsep-konsep dalam ilmu hukum yang berkaitan dengan obyek penelitian dan kemudian dipaparkan secara deskriptif analitif.

\section{Hasil Penelitian dan Pembahasan}

Kedudukan PT. Angkasa Pura I (Persero) dalam Pegadan Tanah untuk Pembangunan Bandara dan Kewajiban PT. Angkasa Pura I (Persero) untuk Membayar BPHTB

Hubungan hukum adalah hubungan antara dua subjek hukum atau lebih atas dasar norma-norma hukum. Hubungan ini ada yang bersifat publik (privaatrechtelijk rechtsbetrekking) dan ada pula yang bersifat privat (publiekrechtelijk rechtsbetrekking). ${ }^{3}$ Selain itu, dimungkinkan pula adanya hubungan yang bersifat campuran atau kombinasi antara hubungan hukum privat dan publik (gemengd rechtsbetrekking). Hubungan hukum privat diatur oleh norma-norma hukum privat seperti perjanjian, jual beli, sewa menyewa, dan sebagainya, sedangkan hubungan hukum publik diatur oleh norma-norma hukum publik seperti delegasi, mandat, dan izin (vergunning). Adapun hubungan hukum yang bersifat campuran contohnya adalah konsesi dan pengadaan barang/jasa pemerintahan.

\footnotetext{
${ }^{3}$ P.J.P. Tak, Rechtsvorming in Nederland, Samsom H.D. Tjeenk Willink Open Universiteit, 1991, hlm. 60.
} 
Telah dikemukakan bahwa PT. Angkasa Pura I (Persero) mendapatkan penugasan khusus dari Menteri BUMN dan Menteri Perhubungan dalam rangka percepatan proses pengadaan tanah bagi pembangunan bandara untuk kepentingan umum di Kabupaten Kulon Progo Provinsi DIY. Istilah penugasan khusus ini terdapat dalam Undang-Undang No. 2 Tahun 2012 tentang Pengadaan Tanah bagi Pembangunan untuk Kepentingan Umum. Hanya saja dalam undangundang ini tidak ditemukan makna, pengertian, ataupun penjelasan dari istilah "penugasan khusus" tersebut, sehingga tidak mudah untuk mengetahui konsekuensi yuridis dan karakteristik hubungan hukumnya antara pemerintah c.q Menteri BUMN dan Menteri Perhubungan selaku pemberi tugas dan PT. Angkasa Pura I (Persero) selaku penerima tugas.

Adanya konsep atau istilah dalam suatu peraturan perundang-undangan yang tidak ditemukan pengertiannya dalam peraturan perundang-undangan yang bersangkutan, secara teoritik dapat merujuk pada peraturan perundang-undangan lain atau merujuk pada doktrin ilmu hukum. Di dalam Undang-Undang No. 30 Tahun 2014 tentang Administrasi Pemerintahan dikenal beberapa instrumen yang berkenaan dengan hubungan hukum pemerintah dengan pihak lain seperti delegasi, mandat, izin, dan konsesi. ${ }^{4}$ Delegasi hanya dapat terjadi dalam hubungan antar instansi pemerintahan, dan mandat hanya dapat dilakukan dalam hubungan internal instansi pemerintahan. Delegasi adalah pelimpahan wewenang dari satu organ pemerintahan kepada organ pemerintahan lainnya, ${ }^{5}$ sedangkan mandat adalah hubungan hukum antara atasan dengan bawahan dalam suatu lingkungan instansi pemerintahan. ${ }^{2}$ PT. Angkasa Pura I (Persero) bukanlah instansi pemerintahan, melainkan sebuah badan hukum perdata, sehingga penugasan

${ }^{4}$ Delegasi adalah pelimpahan Kewenangan dari Badan dan/atau Pejabat Pemerintahan yang lebih tinggi kepada Badan dan/atau Pejabat Pemerintahan yang lebih rendah dengan tanggung jawab dan tanggung gugat beralih sepenuhnya kepada penerima delegasi. Adapun mandat adalah pelimpahan Kewenangan dari Badan dan/atau Pejabat Pemerintahan yang lebih tinggi kepada Badan dan/atau Pejabat Pemerintahan yang lebih rendah dengan tanggung jawab dan tanggung gugat tetap berada pada pemberi mandat. Sedangkan izin keputusan pejabat pemerintahan yang berwenang sebagai wujud persetujuan atas permohonan warga masyarakat sesuai dengan ketentuan peraturan perundang-undangan. Sementara konsesi adalah keputusan Pejabat Pemerintahan yang berwenang sebagai wujud persetujuan dari kesepakatan Badan dan/atau Pejabat Pemerintahan dengan selain Badan dan/atau Pejabat Pemerintahan dalam pengelolaan fasilitas umum dan/atau sumber daya alam dan pengelolaan lainnya sesuai dengan ketentuan peraturan perundang-undangan.

${ }^{5}$ H.D. van Wijk/Willemkonijnenbelt, Op. Cit., hlm. 129.

${ }^{6}$ F.A.M. Stoink dan J.G. Steenbeek, F.A.M. Stoink dan J.G. Steenbeek, Op. Cit., hlm. 46. 
khusus itu tidak dapat dimaknai dalam arti delegasi ataupun mandat. Dengan kata lain, meskipun penugasan itu memiliki makna yang hampir sama dengan delegasi dan mandat, ${ }^{7}$ namun karena PT. Angkasa Pura I (Persero) bukan instansi pemerintahan, maka tidak ada hubungan delegasi ataupun mandat dengan kementerian. Dilihat dari kedudukan hukumnya, maka PT Angkasa Pura bukanlah bagian dari Pemerintah dan tidak dapat disebut sebagai Pemerintah. Kedudukan hukum pejabat pemerintah yang duduk sebagai pemegang saham atau komisaris adalah sama atau setara dengan kedudukan hukum masyarakat biasa atau pemegang saham swasta lainnya, dimana dalam PT tersebut masih terlihat adanya unsur pejabat negara namun kedudukan pejabat negara tersebut bukanlah dalam bobotnya sebagai "negara", melainkan sekedar "pemegang saham biasa", mewakili negara sebagai pemegang saham dalam Rapat Umum Pemegang Saham, sederajat dengan pemegang saham lainnya yang berupa pihak swasta.

Jika penugasan khusus itu dimaknai sebagai izin, maka sebenarnya hal ini secara hukum dapat saja dilakukan, karena pada hakikatnya izin itu merupakan perkenan dari pemerintah berdasarkan undang-undang atau peraturan pemerintah yang disyaratkan untuk perbuatan yang pada umumnya dilarang dan memerlukan pengawasan khusus. ${ }^{8}$ Meskipun demikian, izin ini tidak mengubah kedudukan hukum (rechtspositie) dari PT. Angkasa Pura I (Persero) selaku badan hukum perdata (privaat rechtspersoon) menjadi instansi atau organ pemerintahan. Demikian pula halnya jika menggunakan instrumen konsesi, kedudukan hukum PT. Angkasa Pura I (Persero) tidak berubah menjadi instansi atau organ pemerintahan (bestuursorgaan). Dengan demikian, adanya penugasan khusus yang diterima PT. Angkasa Pura I (Persero) ini secara hukum tidak dapat dijadikan alasan untuk mengelak dari kewajiban untuk membayar BPHTB, lebih-lebih dengan kenyataan bahwa bandar udara itu pada akhirnya dikelola oleh PT. Angkasa Pura I (Persero) sebagai sarana kegiatan bisnis yang berorientasi profit, bukan kegiatan pemerintahan. Oleh karena itu, penugasan khusus tidak dapat menggugurkan kewajiban PT. Angkasa Pura I (Persero) untuk membayar BPHTB.

\footnotetext{
${ }^{7}$ Secara bahasa, delegasi ini berasal dari bahasa Latin delegare artinya melimpahkan urusan atau wewenang, sedangkan mandat dari kata mandare yang berarti memerintahkan atau menugaskan.

${ }^{8}$ N.E. Algra, Rechtsgeleerd Handwoordenboek, Tweede Druk, J.B. Wolters' Uitgeversmaatshappij N.V., Groningen, 1951, hlm. 311.
} 
Penugasan pemerintah kepada BUMN dalam prespektif hukum korporasi dapat dimaknai sebagai penugasan pemerintah pada BUMN yang tidak terlepas dari kedudukan BUMN sebagai salah satu pelaku kegiatan ekonomi dalam perekonomian nasional berdasarkan demokrasi ekonomi di samping BUMN mempunyai peranan penting dalam penyelenggaraan perekonomian nasional guna mewujudkan kesejahteraan masyarakat. ${ }^{9}$ Dalam hal ini penugasan BUMN mempunyai keterkaitan dengan maksud dan tujuan BUMN sebagaimana termaktub dalam Pasal 2 ayat (1) UU Nomor 19 Tahun 2003 tentang BUMN yaitu a). memberikan sumbangan bagi perkembangan perekonomian nasional pada umumnya dan penerimaan negara pada khususnya; b). mengejar keuntungan; c). menyelenggarakan kemanfaatan umum berupa penyediaan barang dan/atau jasa yang bermutu tinggi dan memadai bagi pemenuhan hajat hidup orang banyak; $d$ ). menjadi perintis kegiatan-kegiatan usaha yang belum dapat dilaksanakan oleh sektor swasta dan koperasi; e). turut aktif memberikan bimbingan dan bantuan kepada pengusaha golongan ekonomi lemah, koperasi, dan masyarakat.

Meskipun memiliki fungsi demikian, PT. Angkasa Pura I (Persero) tetap bukanlah instansi pemerintahan, melainkan badan hukum perdata, dan karenanya tidak ada hubungan delegasi ataupun mandat. Dengan kata lain, jika Menteri BUMN dan Menteri Perhubungan menganggap bahwa penugasan khusus itu berupa mandat kepada PT. Angkasa Pura I (Persero), maka anggapan ini tidak dibenarkan secara hukum atau tergolong sebagai anggapan yang tidak sah (onrechtmatig).

Telah disebutkan bahwa penugasan khusus kepada PT. Angkasa Pura I (Persero) dalam rangka percepatan proses pengadaan tanah bagi pembangunan bandara untuk kepentingan umum di Kabupaten Kulon Progo Provinsi DIY itu tertuang dalam Surat Keputusan Menteri Perhubungan No. KP.280 Tahun 2015. Secara hukum, surat keputusan Menteri ini disebut beschikking, dengan unsurunsur; 10

9 Muhammad Insa Ansari, "Penugasan Pemerintah Pada Badan Usaha Milik Negara Sektor Ketanagalistrikan Dalam Prespektif Hukum Korporasi”, Padjadjaran Jurnal Ilmu Hukum, Vol. 4, No. 3, Tahun 2017 , hlm. 561.

${ }^{10}$ Unsur-unsur beschikking ini disarikan dari H.D. van Wijk/Willemkonijnenbelt, ibid, hlm. 203-205, J.B.J.M. ten Berge, Besturen Door de Overbeid, W.E.J. Tjeenk Willink, Deventer, 1996, hlm. 159-162, De Haan, P., et. 
a) Pernyataan kehendak sepihak;

b) Dikeluarkan oleh organ pemerintahan (bestuursorgaan);

c) Didasarkan pada kewenangan hukum yang bersifat publik atau berdasarkan peraturan perundang-undangan;

d) Ditujukan untuk hal khusus atau peristiwa konkret dan individual;

e) Dengan maksud untuk menimbulkan akibat hukum.

Maka Keputusan Menteri tersebut dapat dikategorikan sebagai produk hukum dari Badan/ Pejabat administrasi pemerintahan yang berupa dokumendokumen yang mengandung materi yang bersifat konkrit, individual, dan final dalam hukum administrasi disebut dengan keputusan (Beschikking). ${ }^{11}$

Surat Keputusan Menteri Perhubungan tersebut, seperti hal keputusan pada umumnya, tidak boleh bertentangan dengan peraturan perundang-undangan. Keputusan tidak dapat menganulir keberlakuaan (rechtsgeldig) norma peraturan perundang-undangan. Undang-Undang No. 28 Tahun 2009 tentang Pajak Daerah dan Retribusi Daerah dan Perda Kebupaten Kulon Progo No. 9 Tahun 2010 tentang Bea Perolehan Hak atas Tanah dan Bangunan telah menentukan bahwa subjek dan wajib pajak BPHTB itu salah satunya adalah badan, dan PT. Angkasa Pura I (Persero) tergolong sebagai badan menurut peraturan perundang-undangan. Dengan demikian, Surat Keputusan Menteri Perhubungan tentang penugasan khusus tersebut tidak dapat menganulir kedudukan hukum PT. Angkasa Pura I (Persero) sebagai salah satu subjek dan wajib pajak BPHTB.

\section{Kualifikasi Pengadaan Tanah untuk Pembangunan Bandara di Kabupaten Kulon Progo}

Pranata hukum yang mengatur pengambilan tanah-tanah penduduk untuk keperluan pembangunan antara lain dilakukan dengan pengadaan tanah. Pengadaan tanah adalah setiap kegiatan yang mendapatkan tanah dengan cara memberikan ganti kerugian kepada yang berhak atas tanah tersebut. ${ }^{12}$ Dalam hal pengadaan tanah yang dibahas di penelitian ini tersalah satu alasan pengecualian

\footnotetext{
al., Bestuursrecht in de Sociale Rechsstaat, Deel 2, Kluwer-Deventer, 1986, hlm. 19, dan L.J.A. Damen, et.al. Bestuursrecht, System, Bevoegdheid, Bevoegdheidsuitoefening, Handhaving, BJU Boom Juridische Uitgevers, Tweede Druk, Den Haag, 2005, hlm. 248-252.

${ }^{11}$ Lutfil Ansori, "Diskresi dan Pertanggungjawaban Pemerintah dalam Penyelenggaraan Pemerintahan", Jurnal Yuridis Volume 2 No.1 Juni 2015, Jakarta, hlm.141.

12 Hengki Andora, "Aktualisasi Nilai-Nilai Pancasila dalam Pengadaan Tanah bagi Pembangunan untuk Kepentingan Umum”, Masalab-Masalah Hukum Universitas Diponegoro Semarang, Jilid 45, No.2, April 2016, Semarang, hlm.107-108.
} 
pembayaran BPHTB sebagaimana ditentukan dalam Pasal 85 ayat (4) huruf b dan Pasal 4 huruf b Perda Kabupaten Kulon Progo No. 9 Tahun 2010 tentang Bea Perolehan Hak atas Tanah dan Bangunan adalah "negara untuk penyelenggaraan pemerintahan dan/atau untuk pelaksanaan pembangunan guna kepentingan umum". Terkait dengan hal ini, apakah pengadaan tanah oleh PT. Angkasa Pura I (Persero) untuk bandara di Kabupaten Kulon Progo itu termasuk dalam kategori "negara untuk penyelenggaraan pemerintahan dan/atau untuk pelaksanaan pembangunan guna kepentingan umum"?

Oloan Sitorus dan Dayat Limbong menyatakan bahwa, dalam konsep kepentingan umum harus memenuhi 3 (tiga) hal, yaitu: 1). unsur peruntukannya; 2). unsur kemanfaatannya; 3). unsur siapakah yang dapat melaksanakan dan unsur sifat dari pembangunan untuk kepentingan umum tersebut. ${ }^{13}$ Definisi otentik yang terdapat dalam Pasal 1 angka 6 Undang-Undang No. 2 Tahun 2012 tentang Pengadaan Tanah bagi Pembangunan untuk Kepentingan Umum, disebutkan bahwa kepentingan umum adalah "kepentingan bangsa, negara, dan masyarakat yang harus diwujudkan oleh pemerintah dan digunakan sebesar-besarnya untuk kemakmuran rakyat". Dari definisi tersebut, unsur-unsur kepentingan umum diantaranya: 1). kepentingan bangsa, negara, dan masyarakat; 2). Diwujudkan oleh pemerintah, baik pusat maupun daerah; 3). Digunakan sebesar-besarnya kemakmuran rakyat.

Meskipun telah didefinisikan sedemikian rupa, namun untuk mencari pengertian kepentingan umum secara pasti masih sulit dilakukan karena pada prakteknya tidak jarang terjadi pencampuran antara hukum privat dengan hukum publik dalam pelaksanaan kegiatan yang disebut sebagai kepentingan umum tersebut. Dapatnya pemerintah menjadi pihak dalam bidang hukum privat dengan kedudukannya sebagai badan hukum publik serta adanya sistem konsesi dalam pelaksanaan pembangunan untuk kepentingan umum menjadikan kegiatankegiatan pembangunan untuk kepentingan umum menjadi rancu karena sulilt dilepaskan dari kepentingan swasta.

Terdapat suatu doktrin (public purpose doctrine) dari Michael G. Kitay, bahwa kepentingan umum di berbagai negara dapat diwujudkan dengan 2 cara, yaitu

${ }^{13}$ Oalan Sitorus dan Dayat Limbong, dalam Jarot Widya Muliawan, Op. Cit., hlm. 4. 
pertama pedoman umum (general guidance). Di sini negara hanya menyatakan bahwa pengadaan tanah untuk kepentigan umum (public purpose). Istilah public purpose bisa saja berubah, misalnya publik menjadi social, general, common, atau collective. Sementara purpose diganti menjadi need, necessity, interest, function, utility, atau use. Negara yang menggunakan "pedoman umum" ini biasanya tidak secara eksplisit mencantumkan dalam peraturan perundang-undangan tentang bidang kegiatan apakah yang disebut sebagai "kepentingan umum". Pengadilanlah yang secara kasuistis menentukan apakah yang disebut sebagai "kepentingan umum."14

Kedua, ketentuan-ketentuan daftar (List Provisions). Daftar ini secara eksplisit menyebutkan macam-macam kepentingan umum, misalnya sekolah, jalan, rumah sakit, banguan pemerintah, dan semacamnya. Bentuk-bentuk yang tidak tercantum dalam daftar tidak bisa dijadikan sebagai dasar pengadaan tanah untuk kepentingan umum. Meskipun demikian, sering kedua pendekatan (pedoman umum dan ketentuan daftar) dikombinasikan dalam rencana pengadaan tanah. ${ }^{15}$

Pasal 10 Undang-Undang Nomor 2 Tahun 2012 mengatur pengadaan tanah untuk kepentingan umum jika digunakan untuk pembangunan:

a). pertahanan dan keamanan nasional; b). jalan umum, jalan tol, terowongan, jalur kereta api, stasiun kereta api, dan fasilitas operasi kereta api; c). waduk, bendungan, bendung, irigasi, saluran air minum, saluran pembuangan air dan sanitasi, dan bangunan pengairan lainnya; d). pelabuhan, bandar udara, dan terminal; e). infrastruktur minyak, gas, dan panas bumi; f). pembangkit, transmisi, gardu, jaringan, dan distribusi tenaga listrik; g). jaringan telekomunikasi dan informatika Pemerintah; h). tempat pembuangan dan pengolahan sampah; i). rumah sakit Pemerintah/Pemerintah Daerah; j). fasilitas keselamatan umum; k). tempat pemakaman umum Pemerintah/Pemerintah Daerah; 1). fasilitas sosial, fasilitas umum, dan ruang terbuka hijau publik; m). cagar alam dan cagar budaya; n). kantor Pemerintah/Pemerintah Daerah/desa; o). penataan permukiman kumuh perkotaan dan/atau konsolidasi tanah, serta perumahan untuk masyarakat berpenghasilan rendah dengan status sewa; $\mathrm{p}$ ). prasarana pendidikan atau sekolah Pemerintah/Pemerintah Daerah; q). prasarana olahraga Pemerintah/Pemerintah Daerah; dan r). pasar umum dan lapangan parkir umum.

${ }^{14}$ Adrian Sutedi, Op. Cit., hlm. 75.

15 Michael G. Kitay dalam Oalan Sitorus dan Dayat Limbong, 2004, hlm. 8 dalam Mukmin Zakie, Pergeseran Makna Kepentingan Umum dalam Pengadaan Tanah untuk Kepentingan Umum (Perbandingan di Indonesia dan di Malaysia), Prosiding Seminar Nasional "Problematika Pertanahan dan Strategi Penyelesaiannya: Reforma Agraria, Pendaftaran Tanah, dan Pengdaan Tanah untuk Pembangunan bagi Kepentingan Umum," Sekolah Tinggi Pertanahan Nasional Bekerjasama dengan Pusat Studi Hukum Agraria-Fakultas Hukum Uiversitas Trisakti, Jakarta 7 Oktober 2017, hlm. 421. 
Berdasarkan uraian tersebut jelas bahwa Undang-Undang Nomor 2 Tahun 2012 menggunakan ketentuan-ketentuan daftar (list provisions) dalam menentukan kegiatan-kegiatan apa saja yang termasuk ke dalam pembangunan untuk kepentingan umum. Pada poin d) jelas disebutkan bahwa pembangunan bandar udara termasuk dalam pembanguan untuk kepentingan umum sehingga pengadaan tanah yang diperuntukkan bagi pembangunan bandar udara termasuk dalam pengadaan tanah bagi pembangunan untuk kepentingan umum. Akan tetapi dalam hal pengadaan tanah yang dilakukan oleh PT. Angkasa Pura I (Persero) masih problematik ketika pengadaan tanah tersebut dilakukan oleh BUMN dengan menggunakan dana dari BUMN (PT. Angkasa Pura I) sebagaimana tertuang dalam surat President Director PT. Angkasa Pura I (Persero) No. AP.I.5063/LB. 05/2013/PB-B tanggal 16 Agustus 2013 perihal Kesanggupan Pembiayaan untuk Pembangunan New Yogyakarta International Airport (NYIA). Selain itu, dalam Pasal 11 ayat (2) Undang-Undang Nomor 2 Tahun 2012 disebutkan bahwa "Dalam hal Instansi yang memerlukan Pengadaan Tanah untuk Kepentingan Umum sebagaimana dimaksud dalam Pasal 10 adalah Badan Usaha Milik Negara, tanahnya menjadi milik Badan Usaha Milik Negara", sehingga tanah yang berada di Kabupaten Kulon Progo yang dibebaskan untuk pendirian banda udara NYIA merupakan aset PT. Angkasa Pura I (Persero).

Terlihat ketidaksikronan dalam Undang-Undang Nomor 2 Tahun 2012 antara Pasal 10 yang merupakan list provisions kegiatan-kegiatan apa saja yang termasuk ke dalam pembangunan untuk kepentingan umum dengan Pasal 11 mengenai kepemilikan aset dan Pasal 52 tentang sumber dana pengadaan tanah untuk kepentingan umum. Salah satu prinsip dalam ilmu hukum menyebutkan bahwa jika suatu atau beberapa aturan tidak memberikan penyelesaian atas sebuah persoalan, maka perlu merujuk kepada ketentuan doktrinal. Maka dari itu perlu melihat pada prinsip-prinsip yang menentukan sebuah kegiatan termasuk dalam pembangunan untuk kepentingan umum. Terdapat tiga prinsip untuk menentukan bahwa suatu kegiatan benar-benar untuk kepentingan umum beserta analisis mengenai pengadaan tanah untuk pendirian bandar udara NYIA yang dilakukan PT. Angkasa Pura I termasuk dalam pengadaan tanah untuk kepentingan umum atau tidak. 
Prinsip dan analisis tersebut, pertama, kegiatan tersebut benar-benar dimiliki oleh pemerintah. Pernyataan ini mengandung batasan bahwa kegiatan kepentingan umum tidak dapat dimiliki oleh perorangan ataupun swasta. Dengan kata lain, swasta dan perorangan tidak dapat memiliki jenis-jenis kegiatan kepentingan umum yang membutuhkan pembebasan tanah-tanah hak maupun negara. Terkait dengan kepemilikan ini perlu melihat pengaturan pendanaan dalam hal pengadaan tanah dalam konteks "negara untuk penyelenggaraan pemerintahan dan/atau untuk pelaksanaan pembangunan guna kepentingan umum", pendanaannya bersumber dari Anggaran Pendapatan dan Belanja Negara (APBN) dan/atau Anggaran Pendapatan dan Belanja Daerah (APBD), sebagaimana ditentukan dalam Pasal 52 ayat (1) Undang-Undang No. 2 Tahun 2011 tentang Pengadaan Tanah bagi Pembangunan untuk Kepentingan Umum dan Pasal 117 Perpres No. 71 Tahun 2012 sebagaimana telah beberapa kali diubah terakhir dengan Perpres No. 30 Tahun 2015 tentang Penyelenggaraan Pengadaan Tanah Bagi Pembangunan untuk Kepentingan Umum, sementara pengadaan tanah untuk bandara New Yogyakarta International Airport (NYIA) itu pendanaannya berasal dari PT. Angkasa Pura I (Persero), sebagaimana tertuang dalam surat President Director PT. Angkasa Pura I (Persero) No. AP.I.5063/LB. 05/2013/PBB tanggal 16 Agustus 2013 perihal Kesanggupan Pembiayaan untuk Pembangunan New Yogyakarta International Airport (NYIA). Terlebih lagi berdasarkan hasil kajian rumusan masalah yang pertama kedudukan PT. Angkasa Pura I (Persero) bukanlah Pemerintah.

Kedua, kegiatan pembangunan terkait dilakukan oleh pemerintah. Kalimat ini memberikan batasan bahwa proses pelaksanaan dan pengelolaan suatu kegiatan untuk kepentingan umum hanya dapat diperankan oleh pemerintah. Berdasarkan Pasal 235 (1) Undang-Undang No. 1 Tahun 2009 tentang Penerbangan disebutkan bahwa, "Pelayanan jasa kebandarudaraan yang dilaksanakan oleh badan usaha bandar udara diselenggarakan berdasarkan konsesi dan/atau bentuk lainnya sesuai ketentuan peraturan perundang-undangan diberikan oleh Menteri dan dituangkan dalam perjanjian", 16 dan dalam Pasal 237 ayat (1) Undang-Undang No. 1 Tahun 2009

${ }^{16}$ Berdasarkan Pasal 1 angka 20 UU No. 30 Tahun 2014 tentang Administrasi Pemerintahan, konsesi adalah Keputusan Pejabat Pemerintahan yang berwenang sebagai wujud persetujuan dari kesepakatan Badan dan/atau Pejabat Pemerintahan dengan selain Badan dan/atau Pejabat Pemerintahan dalam pengelolaan fasilitas umum dan/atau sumber daya alam dan pengelolaan lainnya sesuai dengan ketentuan peraturan perundang-undangan. 
disebutkan bahwa, "Pengusahaan bandar udara sebagaimana dimaksud dalam Pasal 232 ayat (1) yang dilakukan oleh badan usaha bandar udara, seluruh atau sebagian besar modalnya harus dimiliki oleh badan hukum Indonesia atau warga negara Indonesia". Kedua pasal ini jelas-jelas menunjukan bahwa pelaku utama dalam pengelolaan bandar udara adalah badan usaha bandar udara, c.q. PT. Angkasa Pura I (Persero), yang mendapatkan konsesi dari pemerintah.

Pengadaan tanah di Kabupaten Kulon Progo oleh PT. Angkasa Pura I (Persero) itu adalah dalam rangka untuk kegiatan kebandarudaraan, yakni segala sesuatu yang berkaitan dengan penyelenggaraan bandar udara dan kegiatan lainnya dalam melaksanakan fungsi keselamatan, keamanan, kelancaran, dan ketertiban arus lalu lintas pesawat udara, penumpang, kargo dan/atau pos, tempat perpindahan intra dan/atau antarmoda serta meningkatkan pertumbuhan ekonomi nasional dan daerah. ${ }^{17}$ Secara operasional, tidak dapat dihindari bahwa di dalam bandar udara itu ada kegiatan pemerintahan seperti pembinaan kegiatan penerbangan, kepabeanan, keimigrasian, dan kekarantinaan, sebagaimana ditentukan dalam Pasal 226 Undang-Undang No. 1 Tahun 2009 tentang Penerbangan, namun kegiatan pemerintahan ini sifatnya penopang yang tidak terpisahkan dalam pengelolaan kegiatan kebandarudaraan. Adanya beberapa kegiatan pemerintahan di dalam bandar udara itu tidak dapat dimaknai bahwa pengadaan tanahnya dalam arti "negara untuk penyelenggaraan pemerintahan dan/atau untuk pelaksanaan pembangunan guna kepentingan umum", yang dibebaskan dari kewajiban membayar BPHTB. PT. Angkasa Pura I (Persero) bukanlah "negara untuk penyelenggaraan pemerintahan".

Ketiga, tidak mencari keuntungan. Pernyataan ini membatasi tentang fungsi suatu kegiatan untuk kepentingan umum sehingga benar-benar berbeda dengan kepentingan swasta yang bertujuan untuk mencari keuntungan sehingga terkualifikasi bahwa kegiatan untuk kespentingan umum sama sekali tidak boleh mencari keuntungan.

Gunanegara mengatakan bahwa kriteria kepentingan umum yang pertama dan utama adalah tidak untuk mencari keuntungan. Kriteria pertama ini adalah

17 Pasal 1 angka 31 UU No. 1 Tahun 2009 tentang Penerbangan. 
karakter dasar pelayanan publik yang harus dilakukan negara, dan ini sejalan dengan konsep kepentingan umum. ${ }^{18}$ PT. Angkasa Pura I (Persero) adalah Perusahaan Perseroan, yaitu BUMN yang berbentuk perseroan terbatas yang modalnya terbagi dalam saham yang seluruh atau paling sedikit $51 \%$ sahamnya dimiliki oleh Negara Republik Indonesia yang tujuan utamanya mengejar keuntungan. ${ }^{19}$ Dengan demikian, pengadaan tanah oleh PT. Angkasa Pura I (Persero) untuk bandara New Yogyakarta International Airport (NYIA) tidak termasuk dalam kategori "negara untuk penyelenggaraan pemerintahan dan/atau untuk pelaksanaan pembangunan guna kepentingan umum", yang dibebaskan dari kewajiban BPHTB. Pengadaan tanah untuk kepentingan umum yang dibebaskan dari kewajiban BPHTB adalah pengadaan tanah yang dilakukan oleh instansi pemerintah dengan pendanaan yang bersumber dari APBN/APBD.

\section{Penutup}

Berdasarkan hasil analisis di atas dapat disimpulkan bahwa, pertama, PT. Angkasa Pura I (Persero) bukanlah instansi pemerintah melainkan badan hukum perdata, sehingga penugasan khusus itu tidak dapat dimaknai dalam arti delegasi ataupun mandat. Dengan kata lain, meskipun penugasan dari pemerintah c.q Menteri BUMN dan Menteri itu memiliki makna yang hampir sama dengan delegasi dan mandat, namun karena PT. Angkasa Pura I (Persero) bukan instansi pemerintahan, maka tidak ada hubungan delegasi ataupun mandat dengan kementerian. PT. Angkasa Pura I merupakan BUMN yang berbentuk Persero yang tunduk pada Undang-Undang No. 40 Tahun 2007 tentang Perseroan Terbatas. Oleh karena itu penugasan khusus tidak dapat menggugurkan kewajiban PT. Angkasa Pura I (Persero) untuk membayar BPHTB.

Kedua, pengadaan tanah untuk pembangunan bandara New Yogyakarta International Airport (NYIA) yang dilakukan oleh PT. Angkasa Pura I (Persero) di Kabupaten Kulon Progo Provinsi DIY tidak dapat dikualifikasi sebagai "pengadaan tanah untuk pembangunan guna kepentingan umum" yang dibebaskan dari kewajiban membayar BPHTB. Hal tersebut dikarenakan

\footnotetext{
${ }_{18}$ Gunanegara, Hukum Administrasi Negara, Jual Beli, dan Pembebasan Tanah, PT. Tatanusa, Jakarta, 2016, hlm. 88.

19 Pasal 1 angka 2 UU No. 19 Tahun 2003 tentang BUMN.
} 
pengadaan tanah oleh PT. Angkasa Pura I (Persero) tidak memenuhi persyaratan pengadaan tanah untuk pembangunan guna kepentingan umum yang diantaranya adalah bahwa pengadaan tanah tersebut harus dimiliki oleh pemerintah, pengadaan tanah harus dilakukan oleh pemerintah, dan pengadaan tanah tidak ditujukan untuk mencari keuntungan.

Berdasarkan analisis di atas, rekomendasi yang diberikan dalam artikel ini yakni pertama, pengadaan tanah untuk pembangunan guna kepentingan umum telah memiliki dasar hukum yang kuat yaitu Undang-Undang No. 2 Tahun 2012 tentang Pengadaan Tanah bagi Pembangunan untuk Kepentingan Umum, namun beberapa norma dalam undang-undang ini tergolong samar (vagenorm) yang memungkinkan salah tafsir bagi fungsionaris hukum. Oleh karena itu, semestinya para pengambil kebijakan mengkaji norma dengan seksama, cermat, dan mempertimbangkan berbagai hal terkait sebelum mengeluarkan keputusan pengadaan tanah. Kedua, Undang-Undang No. 2 Tahun 2012 tentang Pengadaan Tanah bagi Pembangunan untuk Kepentingan Umum memiliki karakter "memaksa" (dwingen recht), terutama ketika telah terbit izin penetapan lokasi. Meskipun demikian, di dalam undang-undang ini juga ada proses musyawarah yang bertumpu pada asas kesepakatan. Oleh karena itu, sebaiknya dalam proses pengadaan tanah untuk kepentingan umum itu musyawarah dapat dilaksanakan sebaik-baiknya. Ketiga, istilah penugasan khusus dalam undang-undang pengadaan tanah ini hanya diberikan kepada Badan Hukum Milik Negara (BHMN) atau Badan Usaha Milik Negara (BUMN) yang akan mengadakan tanah, yang mengandung makna pemberian izin kepada BHMN/BUMN untuk melaksanakan pengadaan tanah dengan prosedur dan mekanisme yang biasa dilakukan oleh instansi pemerintah. Oleh karena itu, semestinya tidak dimaknai dalam pengertian lain yang dapat menimbulkan problem hukum.

\section{Daftar Pustaka}

\section{Buku}

Algra, N.E., Rechtsgeleerd Handwoordenboek, Tweede Druk, J.B. Wolters' Uitgeversmaatshappij N.V., Groningen, 1951. 
Damen, L.J.A., et.al. Bestuursrecht, System, Bevoegdheid, Bevoegdheidsuitoefening, Handhaving, BJU Boom Juridische Uitgevers, Tweede Druk, Den Haag, 2005.

Gunanegara, Hukum Administrasi Negara, Jual Beli, dan Pembebasan Tanah, PT. Tatanusa, Jakarta, 2016.

Limbong, Bernhard, Hukum Agraria Nasional, margaretha Pustaka, Jakarta, 2012.

Muliawan, Jarot Widya, Pengadaan Tanah untuk Pembangunan, Buku Litera, Yogyakarta.

Tak, P.J.P., Rechtsvorming in Nederland, Samsom H.D. Tjeenk Willink Open Universiteit, 1991.

Ten Berge, J.B.J.M., Besturen Door de Overheid, W.E.J. Tjeenk Willink, Deventer, 1996.

Zakie, Mukmin, Pergeseran Makna Kepentingan Umum dalam Pengadaan Tanah untuk Kepentingan Umum (Perbandingan di Indonesia dan di Malaysia), Prosiding Seminar Nasional "Problematika Pertanahan dan Strategi Penyelesaiannya: Reforma Agraria, Pendaftaran Tanah, dan Pengdaan Tanah untuk Pembangunan bagi Kepentingan Umum," Sekolah Tinggi Pertanahan Nasional Bekerjasama dengan Pusat Studi Hukum AgrariaFakultas Hukum Uiversitas Trisakti, Jakarta, 2017.

\section{Jurnal}

Andora, Hengki, "Aktualisasi Nilai-Nilai Pancasila dalam Pengadaan Tanah bagi Pembangunan untuk Kepentingan Umum", Jurnal Masalah-Masalah Hukum Universitas Diponegoro Semarang, Jilid 45, No. 2, April 2016, Semarang.

Ansari, Muhammad Insa, "Penugasan Pemerintah Pada Badan Usaha Milik Negara Sektor Ketanagalistrikan Dalam Prespektif Hukum Korporasi", Padjadjaran Jurnal Ilmu Hukum, Vol. 4, No. 3, Tahun 2017.

Ansori, Lutfil, "Diskresi dan Pertanggungjawaban Pemerintah dalam Penyelenggaraan Pemerintahan", Jurnal Yuridis Volume 2 No. 1 Juni 2015, Jakarta.

Santoso, Urip, "Perolehan Hak Atas Tanah yang Berasal dari Reklamasi Pantai," Mimbar Hukum, Universitas Gadjah Mada, Volume 27, Nomor 2, Juni 2015, Yogyakarta.

Sa'adah, Nabitatus, "Kelemahan Penerapan Closed List System Serta Implikasinya dalam Pemungutan Bea Perolehan Hak Atas Tanah dan Bangunan," Jurnal Masalah-Masalah Hukum Universitas Diponegoro Semarang, Jilid 43, No.1, Januari 2014, Semarang.

\section{Peraturan Perundang-Undangan:}

Undang-Undang Nomor 19 Tahun 2003 tentang BUMN (Lembaran Negara Republik Indonesia Tahun 2003 Nomor 70). 
Undang-Undang Nomor 1 Tahun 2009 tentang Penerbangan (Tambahan Lembaran Negara Republik Indonesia Nomor 4956).

Undang-Undang Nomor 28 Tahun 2009 tentang Pajak Daerah dan Retribusi Daerah (Tambahan Lembaran Negara Republik Indonesia Nomor 5049).

Undang-Undang Nomor 2 Tahun 2012 tentang Pengadaan Tanah bagi Kepentingan Umum (Tambahan Lembaran Negara Republik Indonesia Nomor 5280).

Peraturan Presiden Nomor 30 Tahun 2015 tentang Penyelenggaraan Pengadaan Tanah Bagi Pembangunan untuk Kepentingan Umum (Lembaran Negara Republik Indonesia Tahun 2015 Nomor 123).

Peraturan Daerah Kabupaten Kulon Progo Nomor 9 Tahun 2010 tentang Bea Perolehan Hak atas Tanah dan Bangunan (Lembaran Daerah Kabupaten Kulon Progo No. 1 Tahun 2010). 